\title{
Development of New Two-Dimensional Small Molecules Based on Benzodifuran for Efficient Organic Solar Cells
}

\author{
Zhengkun Du, ${ }^{[\mathrm{a}, \mathrm{b}]}$ Yanhua Chen, ${ }^{[\mathrm{a}, \mathrm{c}]}$ Weichao Chen, ${ }^{[\mathrm{a}]}$ Shanlin Qiao, ${ }^{[\mathrm{a}]}$ Shuguang Wen, ${ }^{[\mathrm{a}]}$ \\ Qian Liu, ${ }^{[a, c]}$ Dangqiang Zhu, ${ }^{[a, b]}$ Mingliang Sun, ${ }^{*[c]}$ and Renqiang Yang*[a, d]
}

\begin{abstract}
A new organic small molecule, DCA3TBDF, with a 2D benzo[1,2- $\left.b: 4,5-b^{\prime}\right]$ difuran (BDF) moiety as the central core and octyl cyanoacetate units as the end-capped blocks, was designed and synthesized for solution-processed bulk heterojunction solar cells. DCA3TBDF possesses good solubility in common organic solvents such as toluene, $\mathrm{CH}_{2} \mathrm{Cl}_{2}$, chloro-
\end{abstract}

benzene, and $\mathrm{CHCl}_{3}$ and good thermal stability with an onset decomposition temperature with $5 \%$ weight-loss occurring at $361^{\circ} \mathrm{C}$. The DCA3TBDF

Keywords: benzodifuran • donoracceptor systems - heterocycles . organic electronics - small molecules thin film showed a broad absorption at $\lambda=320-700 \mathrm{~nm}$ and high crystallinity. Small-molecule organic solar cells based on DCA3TBDF and [6,6]phenyl- $\mathrm{C}_{61}$-butyric acid methyl ester demonstrated promising power conversion efficiency with a high fill factor under the illumination of AM 1.5G $\left(100 \mathrm{~mW} \mathrm{~cm}^{-2}\right)$.

\section{Introduction}

In the past decade, organic solar cells (OSCs) have attracted much attention owing to their unique advantages, which include their low fabrication cost, their light weight, and their good mechanical flexibility. ${ }^{[1-5]}$ The introduction of low band-gap conjugated polymers has led to tremendous progress in polymer solar cells (PSCs), and promising power conversion efficiencies (PCEs) of over 9\% have been achieved. ${ }^{[6]}$ More recently, solution-processed OSCs based on conjugated small molecules have been developed rapidly because of their definite chemical structure, easy purification,

[a] Z. Du, Y. Chen, Dr. W. Chen, Dr. S. Qiao, Dr. S. Wen, Q. Liu,

D. Zhu, Prof. R. Yang

CAS Key Laboratory of Bio-based Materials

Qingdao Institute of Bioenergy and Bioprocess Technology

Chinese Academy of Sciences

Qingdao 266101 (China)

Fax: $(+86) 532-80662778$

E-mail: yangrq@qibebt.ac.cn

[b] Z. Du, D. Zhu

University of Chinese Academy of Sciences

Beijing 100049 (China)

[c] Y. Chen, Q. Liu, Prof. M. Sun

Institute of Materials Science and Engineering

Ocean University of China

Qingdao 266100 (China)

E-mail:mlsun@ouc.edu.cn

[d] Prof. R. Yang

Institute of Polymer Optoelectronic Materials and Devices State Key Laboratory of Luminescent Materials and Devices South China University of Technology Guangzhou 510640 (China)

Supporting information for this article is available on the WWW under http://dx.doi.org/10.1002/asia.201402467. and good synthetic reproducibility. ${ }^{[7-13]}$ Small-molecule organic solar cells (SMOSCs) based on planar linear acceptordonor-acceptor (A-D-A) type molecules have achieved PCEs over $8 \%,{ }^{[8,12]}$ which is very close to the highest PCE of $9.2 \%$ reported for PSCs. ${ }^{[6]}$ So far, this relatively low PCE is still a bottleneck in the commercial application of solution-processed SMOSCs. Hence, new low band-gap small molecules need to be designed and synthesized to improve device performance.

To obtain ideal small-molecule donor materials for highperformance OSCs, the synthesis of low band-gap small molecules containing electron-donating groups and electronwithdrawing groups has become a widely used strategy over the past few years. ${ }^{[8,10,12]}$ Among the variety of developed electron-donating materials for SMOSCs, heterocyclic molecules with planar structures have received considerable attention. Recently, benzo[1,2- $\left.b: 4,5-b^{\prime}\right]$ dithiophene (BDT) has emerged as a promising electron-donating material for photovoltaic applications owing to its relatively convenient modification and planar conjugated structure, which can enhance $\pi-\pi$ stacking in the solid state and enhance electron delocalization.$^{[14-19]}$ To date, SMOSCs based on BDT derivatives have achieved PCEs over $8 \% .{ }^{[12]}$ Although the structure of benzo[1,2-b:4,5- $\left.b^{\prime}\right]$ difuran (BDF) is similar to that of BDT, the oxygen atom possesses a smaller diameter and higher electronegativity than a sulfur atom, ${ }^{[20-23]}$ which may result in good packing of BDF-based molecular backbones. Polymers based on BDF have achieved promising PCEs. Hou et al. reported an alternating 2D copolymer of BDF and thieno[3,4- $b$ ]thiophene (TT), namely, PBDFTT-CF-T, as a donor material and obtained a high PCE of over $6 \% .^{[24]}$ However, small molecules with a BDF moiety as the building block for solution-processed OSCs have not been report- 
ed so far. Therefore, the development of BDF-based small molecules may be a strategic choice for solution-processed SMOSCs.

Alkyl cyanoacetates have a simple conjugated structure and strong electron-withdrawing ability. ${ }^{[12]}$ In most cases, not only does the introduction of an alkyl cyanoacetate effectively regulate the energy levels of the highest occupied molecular orbital (HOMO) and lowest unoccupied molecular orbital (LUMO) but it also improves the solubility of the targeted molecules. According to the literature, the alkyl cyanoacetate group is a widely used acceptor for constructing high-performance SMOSCs. ${ }^{[7,9,12]}$

Considering the above discussions, the investigation of BDF-based small molecules with an alkyl cyanoacetate group as an electron acceptor should be a new donor material for the development of SMOSCs. In this work, we successfully synthesized a novel 2D organic small molecule, DCA3TBDF (Scheme 1), based on 4,8-bis[5-(2-ethylhex-

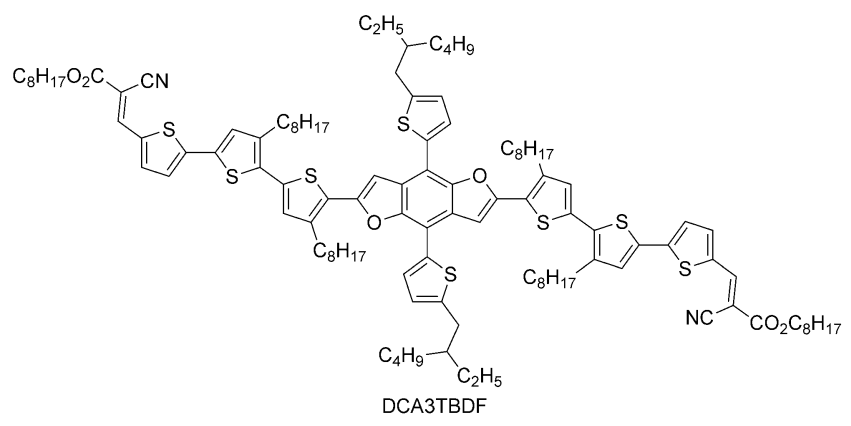

Scheme 1. Molecular structure of DCA3TBDF.

yl)thiophen-2-yl]benzo[1,2- $\left.b: 4,5-b^{\prime}\right]$ difuran as the central core with octyl cyanoacetate units as the end-capped blocks. DCA3TBDF possesses good solubility in common organic solvents, such as toluene, chlorobenzene, $\mathrm{CH}_{2} \mathrm{Cl}_{2}$, and $\mathrm{CHCl}_{3}$. It also shows high crystallinity in the DCA3TBDF/ $\mathrm{PC}_{61} \mathrm{BM} \quad$ blend $\quad\left(\mathrm{PC}_{61} \mathrm{BM}=[6,6]\right.$-phenyl- $\mathrm{C}_{61}$-butyric acid methyl ester). The SMOSC based on DCA3TBDF/PC ${ }_{61} \mathrm{BM}$ exhibits a PCE of $4.49 \%$ with an open-circuit voltage $\left(V_{\text {oc }}\right)$ of $0.90 \mathrm{~V}$, a short-circuit current density $\left(J_{\text {sc }}\right)$ of $7.32 \mathrm{~mA} \mathrm{~cm}^{-2}$, and a high fill factor (FF) of $67.97 \%$.

\section{Results and Discussion}

\section{Synthesis and Characterization}

The detailed synthetic route to DCA3TBDF is given in Scheme 2. The key intermediate, 5"-bromo-4',4"-dioctyl2,2':5',2"'-trithiophene-5-carbaldehyde (5), was synthesized through a four-step reaction from 5-bromothiophene-2-carbaldehyde (1) by using Stille coupling and bromination reactions. BDF-containing dicarbaldehyde precursor 7 was synthesized by a $\left[\mathrm{Pd}\left(\mathrm{PPh}_{3}\right)_{4}\right]$-catalyzed Stille coupling reaction between 5 and 2,6-bis(trimethyltin)-4,8-bis[5-(2-ethylhexyl)thiophen-2yl]benzo[1,2- $b: 4,5-b^{\prime}$ ]difuran (6) in refluxing toluene under argon protection for $36 \mathrm{~h}$. The target DCA3TBDF small molecule was obtained through Knoevenagel condensation of intermediate 7 with octyl cyanoacetate by using triethylamine as the catalyst in anhydrous $\mathrm{CHCl}_{3}$ for $40 \mathrm{~h}$ at room temperature. The structures of all intermediates were verified by NMR spectroscopy. The molecular structure and purity of DCA3TBDF was confirmed by ${ }^{1} \mathrm{H}$ NMR spectroscopy, elemental analysis, and high-resolution mass spectrometry. At relatively low temperatures $\left(40-80^{\circ} \mathrm{C}\right)$, the compound shows good solubility in common organic solvents such as toluene, $\mathrm{CH}_{2} \mathrm{Cl}_{2}, o$-chlorobenzene $(o-\mathrm{DCB}), \mathrm{CHCl}_{3}$, and trichlorobenzene (TCB).

\section{Thermal Stability}

Thermal stability of the small molecule is very important for fabrication of its photovoltaic device. As shown in Figure 1, thermogravimetric analysis (TGA) of DCA3TBDF indicates good thermal stability; the onset decomposition temperature

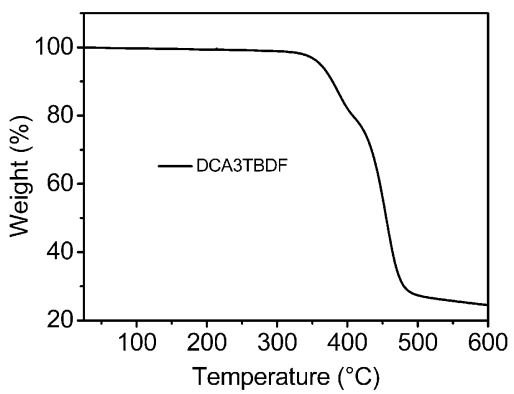

Figure 1. TGA curve of DCA3TBDF at a heating rate of $10^{\circ} \mathrm{Cmin}^{-1}$ under a nitrogen atmosphere.

$\left(T_{\mathrm{d}}\right)$ with $5 \%$ weight loss occurs at $361^{\circ} \mathrm{C}$ under a $\mathrm{N}_{2}$ atmosphere. Such high thermal stability could prevent the deformation of the morphology of a DCA3TBDF film and also prevent the degradation of the small-molecular active layer under applied solution-processed SMOSCs.

\section{Optical Properties}

The normalized UV/Vis absorption spectra of DCA3TBDF in diluted $\mathrm{CHCl}_{3}$ solution and in the film are shown in Figure 2. In solution, DCA3TBDF displays an absorption band at $\lambda=320-625 \mathrm{~nm}$ and a maximum absorption band at $\lambda=520 \mathrm{~nm}$. As a film, DCA3TBDF shows two absorption bands at $\lambda=582$ and $635 \mathrm{~nm}$. The long wavelength absorption is mainly caused by the strong D-A charge-transfer state. ${ }^{[19]}$ The absorption of DCA3TBDF in the solid state is strongly redshifted and broader than that in solution, which indicates that the extended 2D BDF planar system of DCA3TBDF is beneficial in promoting $\pi-\pi$ stacking interactions. ${ }^{[24-26]}$ The optical band gap calculated from the absorption edge $(690 \mathrm{~nm})$ of the thin film is approximately $1.80 \mathrm{eV}$. 

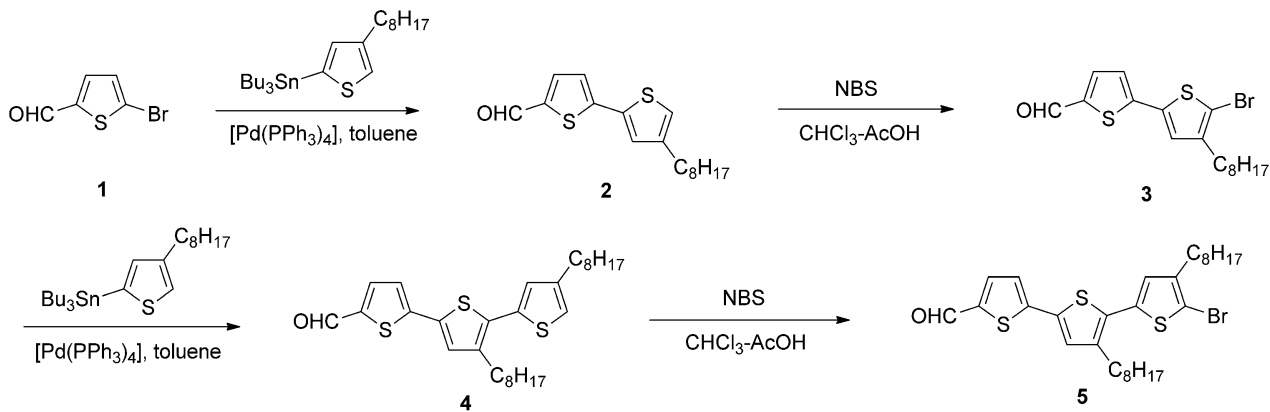
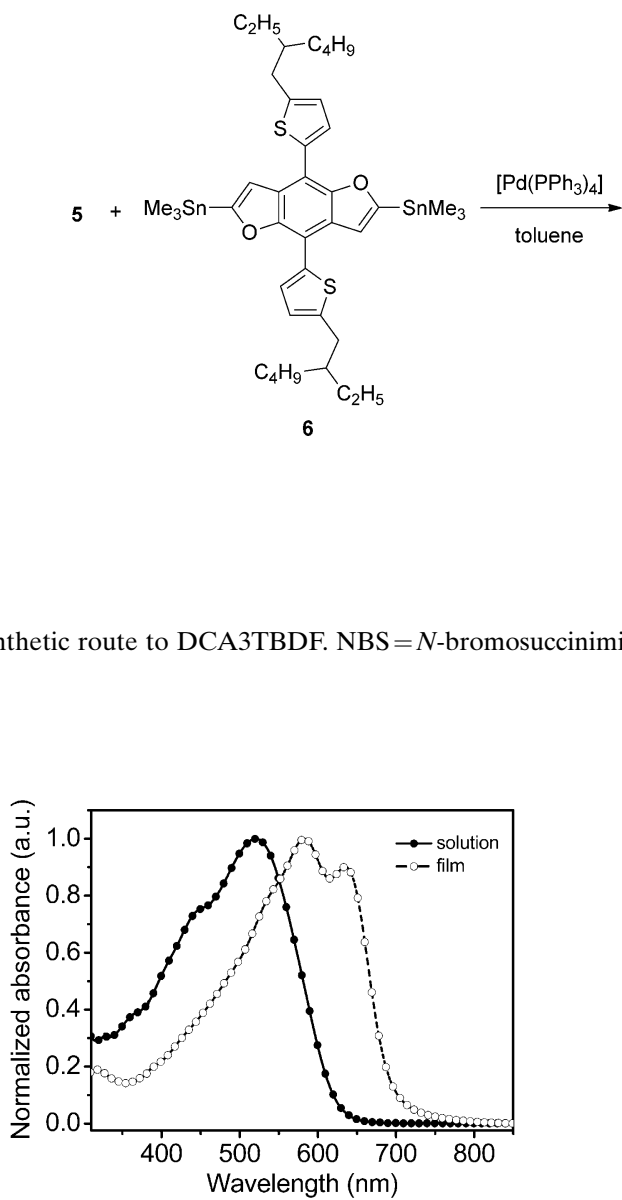

Figure 2. UV/Vis absorption spectra of DCA3TBDF in dilute $\mathrm{CHCl}_{3}$ solution and in thin film.

\section{Electrochemical Properties}

The electrochemical properties of DCA3TBDF were investigated by cyclic voltammetry by using a platinum working electrode in $0.1 \mathrm{M} \mathrm{Bu}_{4} \mathrm{NPF}_{6} / \mathrm{CH}_{3} \mathrm{CN}$ solution with a scan rate of $100 \mathrm{mV} \mathrm{s}^{-1}$. The onset potential of the oxidation wave of DCA3TBDF was $0.80 \mathrm{~V}$ versus $\mathrm{Ag} / \mathrm{AgCl}$ (Figure 3), which corresponds to a HOMO energy level of $-5.12 \mathrm{eV}$. As is well known, $V_{\text {oc }}$ is mainly dependent on the difference between the energy level of the HOMO of the donor and the energy level of the LUMO of the acceptor (usually fullerene derivatives as the acceptor). ${ }^{[13]}$ DCA3TBDF possesses

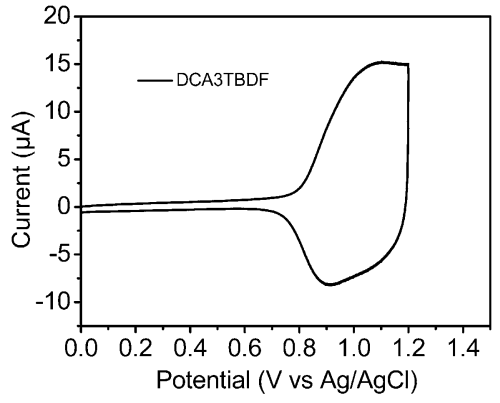

Figure 3. Cyclic voltammogram of a DCA3TBDF film casting on a platinum disk in $0.1 \mathrm{M} \mathrm{Bu}_{4} \mathrm{NPF}_{6} / \mathrm{CH}_{3} \mathrm{CN}$ solution at a scan rate of $100 \mathrm{mV} \mathrm{s}^{-1}$.

a low-lying HOMO energy level because of the strong electron-accepting ability of the alkyl cyanoacetate unit and the 2D conjugated substituted side chain. Thus, high values of $V_{\text {oc }}$ for SMOSCs based on DCA3TBDF and $\mathrm{PC}_{61} \mathrm{BM}$ could be expected. The LUMO energy level was determined to be approximately $-3.32 \mathrm{eV}$ by using its HOMO energy level and the optical band gap. The calculated LUMO energy level of DCA3TBDF is approximately $0.88 \mathrm{eV}$ above the LUMO level $(-4.2 \mathrm{eV})$ of $\mathrm{PC}_{61} \mathrm{BM}$ as an n-type electron acceptor, which generates a large driving force for the transfer and separation of photogenerated charge carriers in the DA interface. ${ }^{[3]}$ 


\section{Photovoltaic Properties}

The photovoltaic properties of DCA3TBDF were investigated with the conventional device structure of ITO/PEDOT:PSS/DCA3TBDF: $\mathrm{PC}_{61} \mathrm{BM} / \mathrm{Ca} / \mathrm{Al} \quad[\mathrm{ITO}=$ indium tin oxide, $\quad$ PEDOT:PSS = poly(3,4-ethylenedioxythiophene) polystyrene sulfonate]. Details of the fabrication and measurements of the device are described in the Experimental Section. The corresponding characteristics of the resulting devices are summarized in Table 1. First, different weight

Table 1. The photovoltaic performance of SMOSCs based on $\mathrm{DCA} 3 \mathrm{TBDF} / \mathrm{PC}_{61} \mathrm{BM}(\mathrm{D} / \mathrm{A})$ with different blend ratios.

\begin{tabular}{llllll}
\hline $\begin{array}{l}\text { Donor/acceptor } \\
(\mathrm{D} / \mathrm{A})\end{array}$ & $\begin{array}{l}\text { Annealing } \\
{\left[{ }^{\circ} \mathrm{C}\right]}\end{array}$ & $\begin{array}{l}V_{\text {oc }} \\
{[\mathrm{V}]}\end{array}$ & $\begin{array}{l}J_{\text {sc }} \\
{\left[\mathrm{mAcm}^{-2}\right]}\end{array}$ & $\begin{array}{l}\mathrm{FF} \\
{[\%]}\end{array}$ & $\begin{array}{l}\text { PCE } \\
{[\%]}\end{array}$ \\
\hline $1: 1$ & no & 0.87 & 5.76 & 64.39 & 3.23 \\
$2: 1$ & no & 0.90 & 6.54 & 65.25 & 3.84 \\
$3: 1$ & no & 0.90 & 2.71 & 60.29 & 1.47 \\
$2: 1$ & 50 & 0.89 & 6.70 & 66.15 & 4.14 \\
$2: 1$ & 70 & 0.90 & 7.32 & 67.97 & 4.49 \\
$2: 1$ & 90 & 0.89 & 7.25 & 64.86 & 4.20 \\
\hline
\end{tabular}

[a] Thermal annealing for $10 \mathrm{~min}$.

ratios of $\mathrm{DCA} 3 \mathrm{TBDF}$ and $\mathrm{PC}_{61} \mathrm{BM}(1: 1,2: 1$, and $3: 1)$ were investigated to optimize the performance of the device. With increasing $\mathrm{D} / \mathrm{A}$ ratio in the active layer, the best performance was achieved with $\mathrm{DCA} 3 \mathrm{TBDF} / \mathrm{PC}_{61} \mathrm{BM}=2: 1$, which reached a PCE of $3.84 \%$ with $V_{\mathrm{oc}}=0.90 \mathrm{~V}, J_{\mathrm{sc}}=$ $6.54 \mathrm{~mA} \mathrm{~cm}^{-2}$, and $\mathrm{FF}=65.25 \%$ without annealing. If the D/ A blend ratio was increased to $3: 1$, the PCE of the SMOSC was reduced markedly to $1.47 \%$ as a result of a reduction in the values of $J_{\mathrm{sc}}$ and FF.

To further improve the photovoltaic performance of SMOSCs based on DCA3TBDF/ $\mathrm{PC}_{61} \mathrm{BM}$, thermal annealing at different temperatures was employed. By increasing the thermal annealing temperature, the values of $J_{\mathrm{sc}}$ and FF of the device first increased and then decreased noticeably. After thermal annealing at $70^{\circ} \mathrm{C}$, the optimized device performance was obtained at a blend ration of 2:1, with a PCE of $4.49 \%, V_{\mathrm{oc}}=0.90 \mathrm{~V}, J_{\mathrm{sc}}=7.32 \mathrm{mAcm}^{-2}$, and $\mathrm{FF}=67.97 \%$. The absorption intensity of the DCA3TBDF/PC ${ }_{61} \mathrm{BM}$ blend film was enhanced by increasing the thermal annealing temperature (see Figure S2), which was thought to be the main reason for the increased value of $J_{\text {sc }}$ for the devices. The high value of FF may be ascribed to high crystallinity and high carrier mobility of DCA3TBDF in the film. ${ }^{[27]}$ Notably, all the devices exhibited high $V_{\text {oc }}$ values of $0.87-0.90 \mathrm{~V}$ because of the low-lying energy level of the HOMO of DCA3TBDF. ${ }^{[28]}$

The current density versus voltage $(J-V)$ curves of the device with a ratio of $2: 1$ before and after thermal annealing at $70^{\circ} \mathrm{C}$ and the corresponding external quantum efficiency (EQE) curves are shown in Figure 4. The EQE curves of the optimized device covered a broad wavelength range from 320 to $700 \mathrm{~nm}$ with a maximum EQE value of $43 \%$ at $550 \mathrm{~nm}$. The shape of the EQE curve for the DCA3TBDFbased SMOSCs is similar to that of its absorption spectra as
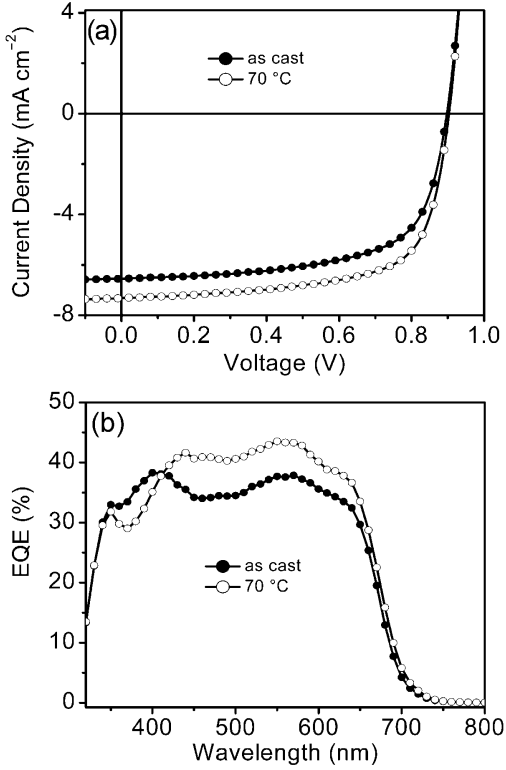

Figure 4. a) $J-V$ characteristics and b) EQE curves of SMOSCs based on DCA3TBDF/PC ${ }_{61} \mathrm{BM}(2: 1 \mathrm{w} / \mathrm{w})$ after thermal annealing at $70^{\circ} \mathrm{C}$.

a thin film. This result demonstrates that most of the absorbed sunlight of DCA3TBDF-based devices contributes to the generation of the photocurrent. ${ }^{[17]}$ The higher EQE value for DCA3TBDF-based OSCs after thermal annealing at $70{ }^{\circ} \mathrm{C}$ results in an increased $J_{\text {sc }}$ value, and this is in agreement with the $J-V$ measurements. The value of $J_{\mathrm{sc}}$ $\left(7.30 \mathrm{~mA} \mathrm{~cm}^{-2}\right)$ calculated from the EQE spectra is consistent with that measured from the $J-V$ curve $\left(7.32 \mathrm{~mA} \mathrm{~cm}^{-2}\right)$.

\section{X-ray Analysis}

Although DCA3TBDF itself possesses eight alkyl side chains, its solubility in chloroform solution was not good at room temperature. This indicates that DCA3TBDF undergoes strong self-aggregation because of the influence of the $\mathrm{BDF}$ unit, which is favorable for ordered arrangement in the solid state. The crystallinity of the DCA3TBDF/PC ${ }_{61} \mathrm{BM}$ thin film before and after thermal annealing at $70^{\circ} \mathrm{C}$ was investigated by X-ray diffraction (XRD) (Figure 5). The film exhibits a narrow (100) reflection peak at $2 \theta=4.04^{\circ}$, which

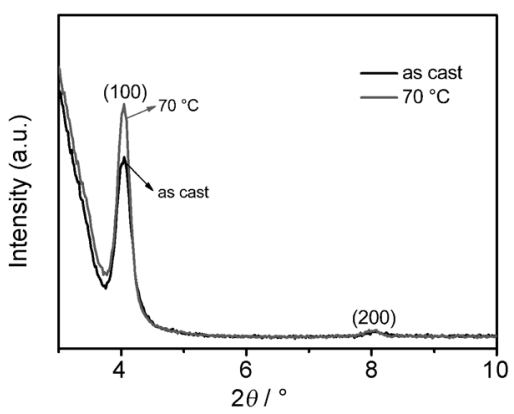

Figure 5. XRD pattern of the $\mathrm{DCA} 3 \mathrm{TBDF} / \mathrm{PC}_{61} \mathrm{BM}$ thin film before and after thermal annealing at $70^{\circ} \mathrm{C}$. 
corresponds to an interlayer spacing of $21.9 \AA$. This spacing value is the distance between the planes of the main conjugated backbone of DCA3TBDF separated by the alkyl side chains. ${ }^{[16]}$ The second-order diffraction peak (200) at $2 \theta=$ $8.08^{\circ}$, corresponding to a $d_{200}$ spacing value of $10.9 \AA$, was also observed, and this is indicative of the high crystallinity of the DCA3TBDF thin film. The higher crystallinity of the film after thermal annealing at $70^{\circ} \mathrm{C}$ could benefit the transport and collection of charge carriers, which may be an important contributor to the high values of $J_{\mathrm{sc}}$ and FF for the devices after annealing.

\section{Hole Mobility}

Hole mobility is another important factor for small molecules owing its direct influence on charge transport. High hole mobility could guarantee effective charge carrier transport to the electrodes and reduce the photocurrent loss in photovoltaic devices. The hole mobility of DCA3TBDF was measured by space-charge limit current (SCLC) ${ }^{[29-31]}$ theory with a device structure of ITO/PEDOT:PSS/ DCA3TBDF: $\mathrm{PC}_{61} \mathrm{BM} / \mathrm{Au}$. The SCLC is described by [Eq. (1)]:[31]

$J_{\mathrm{SCLC}}=\frac{9}{8} \varepsilon_{0} \varepsilon_{\mathrm{r}} \mu_{\mathrm{h}} \frac{V^{2}}{L^{3}}$

in which $J$ stands for current density, $\varepsilon_{0}$ is the permittivity of free space, $\varepsilon_{\mathrm{r}}$ is the relative dielectric constant of the transport medium, $\mu_{\mathrm{h}}$ is the hole mobility, $V$ is the internal potential in the device, and $L$ is the thickness of the active layer. The internal potential $V$ is obtained by subtracting the builtin voltage $\left(V_{\mathrm{b}}\right)$ and the voltage drop $\left(V_{\mathrm{s}}\right)$ from the series resistance of the substrate from the applied voltage $\left(V_{\text {appl }}\right)$ according to Equation (2):

$V=V_{\mathrm{appl}}-V_{\mathrm{bi}}-V_{\mathrm{s}}$

As shown in Figure 6, according to Equation (1), the hole mobility of DCA3TBDF before and after thermal annealing at $70^{\circ} \mathrm{C}$ was calculated to be $1.0 \times 10^{-4}$ and $2.3 \times$ $10^{-4} \mathrm{~cm}^{2} \mathrm{~V}^{-1} \mathrm{~s}^{-1}$, respectively. Under the same measurement

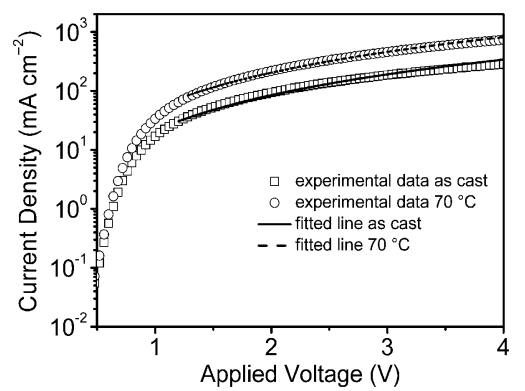

Figure 6 . The $J-V$ curves of the ITO/PEDOT:PSS/DCA3TBDF:PC ${ }_{61} \mathrm{BM}$ $(100 \mathrm{~nm}) / \mathrm{Au}$ diodes before and after thermal annealing at $70^{\circ} \mathrm{C}$. The symbols are experimental data for the transport of holes, and the solid line is fitted according to the space-charge-limited-current model. conditions, the hole mobility of DCA3TBDF was enhanced mainly because of improved intermolecular interactions and ordered alignment of the blend film after thermal annealing. The high mobility would benefit exciton separation and the transport and collection of the charge carrier. ${ }^{[32]}$ Therefore, the values of $J_{\mathrm{sc}}$ and FF were higher for the device after thermal annealing than for the device as cast.

\section{Morphology}

The morphology of the active layer is important for efficient solution-processed SMOSCs, because effective phase separation is very helpful for exciton separation and carrier transport and collection. ${ }^{[33,34]}$ To further understand the relationship between the morphology of the film and the performance of the device, the morphology of the DCA3TBDF/ $\mathrm{PC}_{61} \mathrm{BM}$ blend film before and after thermal annealing was investigated by using tapping-mode atomic force microscopy (AFM). As shown in Figure 7, the pristine film of the DCA3TBDF/ $\mathrm{PC}_{61} \mathrm{BM}$ blend has a root-mean-square (RMS)
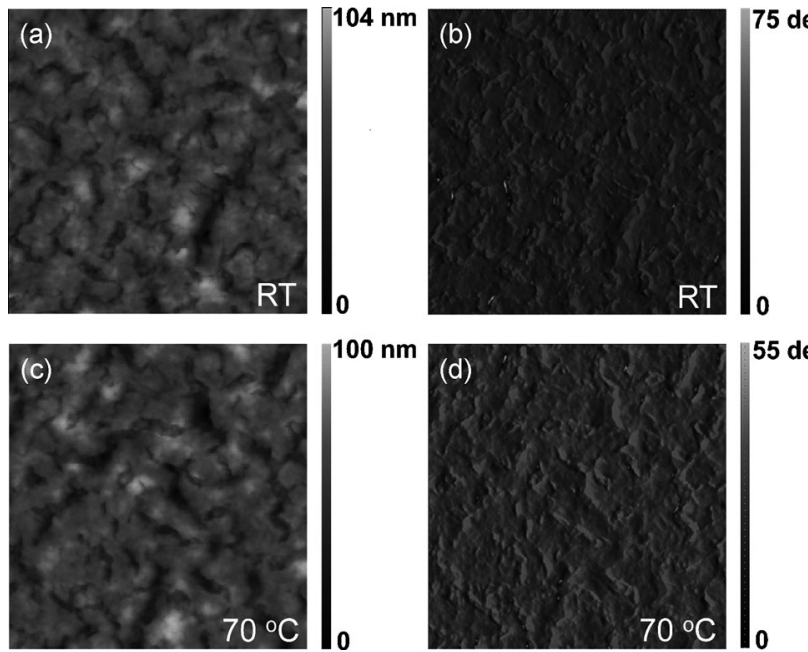

Figure 7. Tapping-mode AFM height $(\mathrm{a}, \mathrm{c})$ and phase $(\mathrm{b}, \mathrm{d})$ images $(4 \times$ $4 \mu \mathrm{m})$ of DCA3TBDF/PC ${ }_{61} \mathrm{BM}(2: 1 \mathrm{w} / \mathrm{w})$ blend film before $(\mathrm{a}, \mathrm{b})$ and after (c,d) thermal annealing at $70^{\circ} \mathrm{C}$.

roughness of $12 \mathrm{~nm}$, and the film after thermal annealing exhibits a RMS roughness of $12.5 \mathrm{~nm}$, which implies a relatively high level of self-organization in the active layer. ${ }^{[32]}$ Owing to the high crystallinity of DCA3TBDF, strong phase aggregation in the thin film is found, which leads to the relatively low value of $J_{\mathrm{sc}}$ for the device.

\section{Conclusions}

In conclusion, a new D-A 2D small molecule, DCA3TBDF, based on benzo[1,2- $\left.b: 4,5-b^{\prime}\right]$ difuran was designed and synthesized. DCA3TBDF exhibited good thermal stability and a HOMO energy level of $-5.12 \mathrm{eV}$. The X-ray diffraction pattern of DCA3TBDF showed that it exhibited ordered 
crystallinity after thermal annealing. A small-molecule organic solar cell device based on DCA3TBDF and $\mathrm{PC}_{61} \mathrm{BM}$ was prepared and it showed a power conversion efficiency of $4.49 \%$ with a high fill factor $(67.97 \%)$ after thermal annealing at only $70^{\circ} \mathrm{C}$. The results indicate that the benzo[1,2- $\left.b: 4,5-b^{\prime}\right]$ difuran unit may be a promising electrondonor building block for solution-processed SMOSCs.

\section{Experimental Section}

\section{Materials}

All starting materials and reagents were purchased from commercial sources and were used without further purification, unless otherwise mentioned. Toluene was dried with sodium by using benzophenone as an indicator. $\mathrm{CHCl}_{3}$ and $\mathrm{CH}_{2} \mathrm{Cl}_{2}$ were distilled from calcium hydride.

\section{Measurements and characterization}

NMR spectra were measured in $\mathrm{CDCl}_{3}$ with a Bruker Advance III 600 spectrometer with tetramethylsilane $(\delta=0 \mathrm{ppm})$ as an internal standard. High-resolution mass spectra were recorded under the atmospheric pressure chemical ionization mode with a Bruker Maxis UHR TOF spectrometer. UV/Vis absorption spectra were obtained with a Hitachi U4100 spectrophotometer. The surface roughness and morphology of the thin films were characterized by atomic force microscopy (AFM) with an Agilent 5400. The structure of the films was performed with grazing incidence X-ray diffraction (GIXRD, Bruker D8 ADVANCE). Xyclic voltammetry (CV) measurements were taken with a CHI660D electrochemical workstation in $0.1 \mathrm{~m}$ tetrabutylammonium phosphorus hexafluoride $\left(\mathrm{Bu}_{4} \mathrm{NPF}_{6}\right) /$ acetonitrile solution at a scan rate of $100 \mathrm{mV} \mathrm{s}^{-1}$ by using a platinum wire as the counter electrode, a $\mathrm{Ag} / \mathrm{AgCl}$ electrode as the reference electrode, and a platinum working electrode coated with DCA3TBDF. Ferrocene/ferrocenium $\left(\mathrm{Fc} / \mathrm{Fc}^{+}\right)$was used as the internal standard (the energy level of $\mathrm{Fc} / \mathrm{Fc}^{+}$is $-4.8 \mathrm{~V}$ under vacuum), and the formal potential of $\mathrm{Fc} / \mathrm{Fc}^{+}$was $0.38 \mathrm{~V}$ vs. an $\mathrm{Ag} / \mathrm{AgCl}$ electrode.

\section{Fabrication and characterization of the SMOSCs}

The bulk heterojunction SMOSCs based on DCA3TBDF were fabricated with a structure of ITO/PEDOT:PSS/DCA3TBDF:PC ${ }_{61} \mathrm{BM} / \mathrm{Ca} / \mathrm{Al}$ by using the conventional solution spin-coating process. The ITO-coated glass substrates were cleaned by sequential ultrasonic treatment in detergent, deionized water, acetone, and isopropyl alcohol for $20 \mathrm{~min}$ and subsequently oxygen plasma treatment was made for $10 \mathrm{~min}$ as the final step. Then, a thin layer of PEDOT:PSS was spin coated onto the ITO surface with a thickness of approximately $40 \mathrm{~nm}$. After baking at $150^{\circ} \mathrm{C}$ for $25 \mathrm{~min}$, the substrates were transferred into a glove box. Subsequently, the active layer was spin coated in different blend ratios of DCA3TBDF and $\mathrm{PC}_{61} \mathrm{BM}$ in $\mathrm{CHCl}_{3}$ solution at $1500 \mathrm{rpm}$ for $20 \mathrm{~s}$. Finally, a $10 \mathrm{~nm}$ Ca layer and a $100 \mathrm{~nm} \mathrm{Al}$ layer were successively deposited onto the active layer under high vacuum $\left(<2.5 \times 10^{-4} \mathrm{~Pa}\right)$. Thermal annealing was performed by placing the completed devices on a digitally controlled hotplate at $70^{\circ} \mathrm{C}$ in an argon-filled glove box.

The current density-voltage $(J-V)$ characteristics of the devices were measured with a Keithley 2420 source measurement unit under simulated $100 \mathrm{~mW} \mathrm{~cm}^{-2}$ (AM1.5 G) irradiation from a Newport solar simulator. Light intensity was calibrated with a standard silicon solar cell. The external quantum efficiencies were analyzed by using a certified Newport incident photon conversion efficiency measurement system.

\section{Synthesis}

All coupling reactions were conducted under an argon atmosphere. 2(Tributylstannyl)-4-octylthiophen and 2,6-bis(trimethyltin)-4,8-bis[5-(2ethylhexyl)thiophen-2-yl]benzo[1,2-b:4,5-b']difuran (6) were synthesized according to literature procedures. ${ }^{[24]}$

\section{Compound 2}

A $100 \mathrm{~mL}$ flame-dried flask was charged with 2-(tributylstannyl)-4-octylthiophene $(4.95 \mathrm{~g}, \quad 10.0 \mathrm{mmol}), \quad 5$-bromothiophene-2-carbaldehyde $(1.53 \mathrm{~g}, 8.0 \mathrm{mmol})$, and anhydrous toluene $(35 \mathrm{~mL})$. The mixture was degassed with argon for $30 \mathrm{~min}$. $\left[\mathrm{Pd}\left(\mathrm{PPh}_{3}\right)_{4}\right](0.23 \mathrm{~g}, 0.2 \mathrm{mmol})$ was added. The mixture was slowly heated up to $100^{\circ} \mathrm{C}$ and stirred at this temperature overnight under an argon atmosphere. Then, water was added, and the mixture was extracted with $\mathrm{CH}_{2} \mathrm{Cl}_{2}(3 \times)$. The combined organic layer was dried with anhydrous $\mathrm{Na}_{2} \mathrm{SO}_{4}$. After removing the solvent under reduced pressure, the crude residue was purified by column chromatography (silica gel, petroleum ether $\left./ \mathrm{CH}_{2} \mathrm{Cl}_{2}\right)$. Finally, $2(1.59 \mathrm{~g}, 65 \%)$ was obtained as a light yellow solid. ${ }^{1} \mathrm{H}$ NMR $\left(600 \mathrm{MHz}, \mathrm{CDCl}_{3}\right): \delta=9.85$ (s, $1 \mathrm{H}), 7.65(\mathrm{~d}, 1 \mathrm{H}), 7.21(\mathrm{~d}, 1 \mathrm{H}), 7.19(\mathrm{~d}, 1 \mathrm{H}), 6.95(\mathrm{~s}, 1 \mathrm{H}), 2.60(\mathrm{t}, 2 \mathrm{H})$, $1.63(\mathrm{~m}, 2 \mathrm{H}), 1.35-1.25(\mathrm{~m}, 10 \mathrm{H}), 0.88 \mathrm{ppm}(\mathrm{t}, 3 \mathrm{H}) .{ }^{13} \mathrm{C}$ NMR $(150 \mathrm{MHz}$, $\left.\mathrm{CDCl}_{3}\right): \delta=182.53,147.68,144.79,141.45,137.35,135.63,127.46,123.91$, $121.93,31.87,30.40,30.38,29.39,29.27,29.25,22.67,14.11 \mathrm{ppm}$

\section{Compound 3}

$N$-Bromosuccinimide (NBS; $0.89 \mathrm{~g}, 5.0 \mathrm{mmol}$ ) was added in small portions to a solution of $2(1.53 \mathrm{~g}, 5.0 \mathrm{mmol})$ in $\mathrm{CHCl}_{3}(35 \mathrm{~mL})$ and acetic acid $(35 \mathrm{~mL})$. In the absence of light, the mixture was stirred for $6 \mathrm{~h}$ at room temperature. The mixture was diluted with water and extracted with $\mathrm{CH}_{2} \mathrm{Cl}_{2}(3 \times)$. The organic phase was dried with $\mathrm{Na}_{2} \mathrm{SO}_{4}$. After removing the solvent under reduced pressure, the crude product was purified by column chromatography (silica gel, petroleum ether $/ \mathrm{CH}_{2} \mathrm{Cl}_{2}$ ). Compound $3(1.35 \mathrm{~g}, 70 \%)$ was obtained as a yellow solid. ${ }^{1} \mathrm{H}$ NMR $\left(600 \mathrm{MHz}, \mathrm{CDCl}_{3}\right): \delta=9.84(\mathrm{~s}, 1 \mathrm{H}), 7.62(\mathrm{~d}, 1 \mathrm{H}), 7.13(\mathrm{~d}, 1 \mathrm{H}), 7.02(\mathrm{~s}$, $1 \mathrm{H}), 2.53(\mathrm{t}, 2 \mathrm{H}), 1.58(\mathrm{~m}, 2 \mathrm{H}), 1.33-1.25(\mathrm{~m}, 10 \mathrm{H}), 0.88 \mathrm{ppm}(\mathrm{t}, 3 \mathrm{H})$ ${ }^{13} \mathrm{C}$ NMR $\left(150 \mathrm{MHz}, \mathrm{CDCl}_{3}\right): \delta=182.37,146.25,143.66,141.72,137.22$, $135.39,126.75,124.03,110.96,31.86,29.60,29.52,29.34,29.22,29.20$, 22.67, $14.12 \mathrm{ppm}$

\section{Compound 4}

A $50 \mathrm{~mL}$ flame-dried flask was charged with $\mathbf{3}(1.15 \mathrm{~g}, 3.0 \mathrm{mmol})$, 2-(tributylstannyl)-4-octylthiophene ( $1.58 \mathrm{~g}, 3.25 \mathrm{mmol})$, and anhydrous toluene $(20 \mathrm{~mL})$. The mixture was degassed with argon for $30 \mathrm{~min}$. $\left[\mathrm{Pd}\left(\mathrm{PPh}_{3}\right)_{4}\right]$ (91 mg, $0.08 \mathrm{mmol}$ ) was added quickly. The mixture was slowly heated up to $100^{\circ} \mathrm{C}$ and stirred at this temperature for $12 \mathrm{~h}$ under an argon atmosphere. Then, the cooled mixture was poured into water and extracted with $\mathrm{CH}_{2} \mathrm{Cl}_{2}(3 \times)$. The combined organic layer was dried with anhydrous $\mathrm{Na}_{2} \mathrm{SO}_{4}$. After removing the solvent under reduced pressure, the crude residue was purified by column chromatography (silica gel, petroleum ether $\left./ \mathrm{CH}_{2} \mathrm{Cl}_{2}\right)$. Compound $4(0.9 \mathrm{~g}, 60 \%)$ was obtained as a red solid. ${ }^{1} \mathrm{H}$ NMR $\left(600 \mathrm{MHz}, \mathrm{CDCl}_{3}\right): \delta=9.84(\mathrm{~s}, 1 \mathrm{H}), 7.64(\mathrm{~d}, 1 \mathrm{H}), 7.19(\mathrm{~d}, 1 \mathrm{H})$, $7.17(\mathrm{~s}, 1 \mathrm{H}), 6.99(\mathrm{~d}, 1 \mathrm{H}), 6.93(\mathrm{~s}, 1 \mathrm{H}), 2.73(\mathrm{t}, 2 \mathrm{H}), 2.60(\mathrm{t}, 2 \mathrm{H}), 1.67-$ $1.61(\mathrm{~m}, 4 \mathrm{H}), \quad 1.40-1.27(\mathrm{~m}, 20 \mathrm{H}), 0.88 \mathrm{ppm} \quad(\mathrm{m}, 6 \mathrm{H}) .{ }^{13} \mathrm{C} \mathrm{NMR}$ $\left(150 \mathrm{MHz}, \mathrm{CDCl}_{3}\right): \delta=182.39,147.15,143.87,141.40,140.51,137.40$, $134.84,133.28,133.11,129.00,127.75,123.85,120.79,31.90,31.88,30.50$, $30.46,30.43,29.52,29.44,29.38,29.34,29.30,29.28,29.26,22.68$, $14.12 \mathrm{ppm}$.

\section{Compound 5}

NBS $(0.27 \mathrm{~g}, 1.51 \mathrm{mmol})$ was added in small portions to a solution of 4 $(0.75 \mathrm{~g}, 1.5 \mathrm{mmol})$ in $\mathrm{CHCl}_{3}(25 \mathrm{~mL})$ and acetic acid $(25 \mathrm{~mL})$. In the absence of light, the mixture was stirred for $6 \mathrm{~h}$ at room temperature. The mixture was diluted with water and extracted with $\mathrm{CH}_{2} \mathrm{Cl}_{2}(3 \times)$. The organic phase was dried with $\mathrm{Na}_{2} \mathrm{SO}_{4}$. After removing the solvent under reduced pressure, the crude product was purified by column chromatography (silica gel, petroleum ether/ $\left.\mathrm{CH}_{2} \mathrm{Cl}_{2}\right)$. Compound $5(0.69 \mathrm{~g}, 80 \%)$ was obtained as an orange solid. ${ }^{1} \mathrm{H}$ NMR $\left(600 \mathrm{MHz}, \mathrm{CDCl}_{3}\right): \delta=9.86(\mathrm{~s}$, $1 \mathrm{H}), 7.66(\mathrm{~d}, 1 \mathrm{H}), 7.21(\mathrm{~d}, 1 \mathrm{H}), 7.16(\mathrm{~s}, 1 \mathrm{H}), 6.85(\mathrm{~s}, 1 \mathrm{H}), 2.70(\mathrm{t}, 2 \mathrm{H})$, $2.57(\mathrm{t}, 2 \mathrm{H}), 1.66-1.58(\mathrm{~m}, 4 \mathrm{H}), 1.38-1.25(\mathrm{~m}, 20 \mathrm{H}), 0.89 \mathrm{ppm}(\mathrm{m}, 6 \mathrm{H})$. ${ }^{13} \mathrm{C}$ NMR $\left(150 \mathrm{MHz}, \mathrm{CDCl}_{3}\right): \delta=182.39,146.80,142.69,141.63,141.03$, $137.34,134.65,133.63,132.12,128.91,127.23,124.04,109.57,31.89,31.87$, $30.50,29.67,29.53,29.47,29.38,29.37,29.28,29.25,22.68,14.13$ ppm. MS (UHR-TOF): $\mathrm{m} / \mathrm{z}$ : calcd for $\mathrm{C}_{29} \mathrm{H}_{39} \mathrm{BrOS}_{3}$ : $578.1346\left[\mathrm{M}^{+}\right]$; found: 578.1342. Elemental analysis calcd (\%) for $\mathrm{C}_{29} \mathrm{H}_{39} \mathrm{BrOS}_{3}$ (579.72): $\mathrm{C}$ 60.08, H 6.78, S 16.59; found: C 59.95, H 6.75, S 16.38 . 


\section{Compound 7}

A three-necked $50 \mathrm{~mL}$ flask was charged with $5(0.58 \mathrm{~g}, 1.0 \mathrm{mmol}), \mathbf{6}$ $(0.39 \mathrm{~g}, 0.45 \mathrm{mmol})$, and anhydrous toluene $(20 \mathrm{~mL})$. The mixture was degassed with argon $(3 \times)$. $\left[\mathrm{Pd}\left(\mathrm{PPh}_{3}\right)_{4}\right](46 \mathrm{mg}, 0.04 \mathrm{mmol})$ was added quickly under an argon atmosphere. The mixture was slowly heated up to $100^{\circ} \mathrm{C}$ and stirred at this temperature for $36 \mathrm{~h}$ under an argon atmosphere. Then, the cooled mixture was poured into water and extracted with $\mathrm{CH}_{2} \mathrm{Cl}_{2}(3 \times)$. The combined organic layer was dried with $\mathrm{Na}_{2} \mathrm{SO}_{4}$. After removing the solvent under reduced pressure, the crude residue was purified by column chromatography (silica gel, petroleum ether/ $\left.\mathrm{CH}_{2} \mathrm{Cl}_{2}\right)$. Compound $7(0.42 \mathrm{~g}, 60 \%)$ was obtained as a red solid. ${ }^{1} \mathrm{H}$ NMR (600 MHz, $\left.\mathrm{CDCl}_{3}\right): \delta=9.86(\mathrm{~s}, 2 \mathrm{H}), 7.78(\mathrm{~s}, 2 \mathrm{H}), 7.66(\mathrm{~d}, 2 \mathrm{H})$, $7.44(\mathrm{~d}, 2 \mathrm{H}), 7.23(\mathrm{~d}, 2 \mathrm{H}), 7.20(\mathrm{~s}, 2 \mathrm{H}), 7.05(\mathrm{~s}, 2 \mathrm{H}), 6.94(\mathrm{~d}, 2 \mathrm{H}), 2.99$ $(\mathrm{t}, 2 \mathrm{H}), 2.90(\mathrm{dd}, 2 \mathrm{H}), 2.83(\mathrm{t}, 2 \mathrm{H}), 1.81-1.69(\mathrm{~m}, 10 \mathrm{H}), 1.38-1.26(\mathrm{~m}$, $56 \mathrm{H}), 0.98-0.85 \mathrm{ppm}(\mathrm{m}, 24 \mathrm{H}) .{ }^{13} \mathrm{C}$ NMR $\left(150 \mathrm{MHz}, \mathrm{CDCl}_{3}\right): \delta=182.39$, $151.23,147.95,146.91,144.91,141.67,141.50,141.02,137.40,134.55$, $134.15,133.04,132.70,129.31,129.20,127.57,127.47,125.76,124.85$, $123.96,109.09,103.58,41.53,34.23,32.54,31.96,31.92,30.42,30.08,29.90$, $29.83,29.71,29.63,29.49,29.42,29.33,28.98,25.59,23.09,22.73,22.70$, $14.20,14.13,14.12,10.91 \mathrm{ppm}$. MS (UHR-TOF): $\mathrm{m} / \mathrm{z}$ : calcd for $\mathrm{C}_{92} \mathrm{H}_{118} \mathrm{O}_{4} \mathrm{~S}_{8}: 1542.6796\left[M^{+}\right]$; found: 1542.6869 .

\section{$D C A 3 T B D F$}

Under protection of argon, octyl cyanoacetate $(0.8 \mathrm{~mL}, 3.8 \mathrm{mmol})$ was added by syringe to a stirred solution of $7(0.38 \mathrm{~g}, 0.25 \mathrm{mmol})$ in $\mathrm{CHCl}_{3}$ $(30 \mathrm{~mL})$ and triethylamine $(0.08 \mathrm{~mL})$. The mixture was stirred for $40 \mathrm{~h}$ at room temperature under an argon atmosphere. Then, it was poured into water $(40 \mathrm{~mL})$ and extracted with $\mathrm{CHCl}_{3}(3 \times)$. The organic phase was dried with $\mathrm{Na}_{2} \mathrm{SO}_{4}$. After removing the solvent under reduced pressure, the crude product was purified by column chromatography (silica gel, petroleum ether $\left./ \mathrm{CH}_{2} \mathrm{Cl}_{2}\right)$. DCA3TBDF $(0.38 \mathrm{~g}, 80 \%)$ was obtained as a black solid. ${ }^{1} \mathrm{H}$ NMR $\left(600 \mathrm{MHz}, \mathrm{CDCl}_{3}\right): \delta=8.21(\mathrm{~s}, 2 \mathrm{H}), 7.78(\mathrm{~d}, 2 \mathrm{H})$, $7.60(\mathrm{~d}, 2 \mathrm{H}), 7.39$ (s, 2H), $7.20(\mathrm{~s}, 2 \mathrm{H}), 7.17$ (d, 2H), $7.01(\mathrm{~s}, 2 \mathrm{H}), 6.95$ $(\mathrm{d}, 2 \mathrm{H}), 4.27(\mathrm{t}, 4 \mathrm{H}), 2.95(\mathrm{t}, 4 \mathrm{H}), 2.91(\mathrm{t}, 4 \mathrm{H}), 2.80(\mathrm{t}, 4 \mathrm{H}), 1.74(\mathrm{~m}$, $14 \mathrm{H}), 1.52-1.29(\mathrm{~m}, 76 \mathrm{H}), 0.98(\mathrm{t}, 6 \mathrm{H}), 0.94-0.86 \mathrm{ppm}(\mathrm{m}, 24 \mathrm{H}) . \mathrm{MS}$ (UHR-TOF): $\mathrm{m} / \mathrm{z}$ : calcd for $\mathrm{C}_{114} \mathrm{H}_{152} \mathrm{~N}_{2} \mathrm{O}_{6} \mathrm{~S}_{8}: 1900.9416\left[M^{+}\right]$: found: 1900.9489. Elemental analysis calcd (\%) for $\mathrm{C}_{114} \mathrm{H}_{152} \mathrm{~N}_{2} \mathrm{O}_{6} \mathrm{~S}_{8}$ (1902.96): $\mathrm{C}$ 71.95, H 8.05, N 1.47, S 13.48; found: C 72.01, H 8.03, N 1.43, S 13.42.

\section{Acknowledgements}

This work was supported by the Ministry of Science and Technology of China (2014CB643501, 2010DFA52310), National Natural Science Foundation of China (21274161, 21202181, 51173199, 51211140346), and Shandong Provincial Natural Science Foundation (ZR2011BZ007).

[1] G. Yu, J. Gao, J. C. Hummelen, F. Wudl, A. J. Heeger, Science 1995, 270, 1789-1791.

[2] J. W. Chen, Y. Cao, Acc. Chem. Res. 2009, 42, 1709-1718.

[3] B. C. Thompson, J. M. Fréchet, Angew. Chem. Int. Ed. 2008, 47, 5877; Angew. Chem. 2008, 120, 62-82.

[4] J. H. Hou, H. Y. Chen, S. Q. Zhang, R. I. Chen, Y. Yang, Y. Wu, G. Li, J. Am. Chem. Soc. 2009, 131, 15586-15587.

[5] H. Zhou, L. Yang, W. You, Macromolecules 2012, 45, 607-632.

[6] Z. He, C. Zhong, S. Su, M. Xu, H. Wu, Y. Cao, Nat. Photonics 2012 6, 591-595.

[7] Y. Liu, Y. M. Yang, C. C. Chen, Q. Chen, L. Dou, Z. Hong, G. Li, Y. Yang, Adv. Mater. 2013, 25, 4657-4662.
[8] D. H. Wang, A. K. K. Kyaw, V. Gupta, G. C. Bazan, A. J. Heeger, Adv. Energy Mater. 2013, 3, 1161-1165.

[9] C. Cui, J. Min, C. L. Ho, T. Ameri, P. Yang, J. Zhao, C. J. Brabec, W. Y. Wong, Chem. Commun. 2013, 49, 4409-4411.

[10] S. Loser, C. J. Bruns, H. Miyauchi, R. P. Ortiz, A. Facchetti, S. I. Stupp, T. J. Marks, J. Am. Chem. Soc. 2011, 133, 8142-8145.

[11] J. Liu, Y. Sun, P. Moonsin, M. Kuik, C. M. Proctor, J. Lin, B. B. Hsu, V. Promarak, A. J. Heeger, T. Q. Nguyen, Adv. Mater. 2013, 25, 5898-5903.

[12] J. Zhou, Y. Zuo, X. Wan, G. Long, Q. Zhang, W. Ni, Y. Liu, Z. Li, G. He, C. Li, B. Kan, M. Li, Y. Chen, J. Am. Chem. Soc. 2013, 135, 8484-8487.

[13] A. Tang, L. Li, Z. Lu, J. Huang, H. Jia, C. Zhan, Z. Tan, Y. Li, J. Yao, J. Mater. Chem. A 2013, 1, 5747-5757.

[14] C. Cabanetos, A. El Labban, J. A. Bartelt, J. D. Douglas, W. R. Mateker, J. M. Fréchet, M. D. McGehee, P. M. Beaujuge, J. Am. Chem. Soc. 2013, 135, 4656-4659.

[15] L. Huo, S. Zhang, X. Guo, F. Xu, Y. Li, J. Hou, Angew. Chem. Int. Ed. 2011, 50, 9697-9702; Angew. Chem. 2011, 123, 9871-9876.

[16] J. Min, Z.-G. Zhang, S. Zhang, Y. Li, Chem. Mater. 2012, 24, $3247-$ 3254.

[17] Y. Lin, L. Ma, Y. Li, Y. Liu, D. Zhu, X. Zhan, Adv. Energy Mater 2013, 3, 1166-1170.

[18] Y. Liu, X. Wan, F. Wang, J. Zhou, G. Long, J. Tian, Y. Chen, Adv. Mater. 2011, 23, 5387-5391.

[19] B. Liu, X. Chen, Y. He, Y. Li, X. Xu, L. Xiao, L. Li, Y. Zou, J. Mater. Chem. A 2013, 1, 570-577.

[20] X. Chen, B. Liu, Y. Zou, L. Xiao, X. Guo, Y. He, Y. Li, J. Mater Chem. 2012, 22, 17724-17731.

[21] U. H. Bunz, Angew. Chem. Int. Ed. 2010, 49, 5037-5040; Angew. Chem. 2010, 122, 5159-5162.

[22] C. H. Woo, P. M. Beaujuge, T. W. Holcombe, O. P. Lee, J. M. Fréchet, J. Am. Chem. Soc. 2010, 132, 15547-15549.

[23] O. Gidron, A. Dadvand, Y. Sheynin, M. Bendikov, D. F. Perepichka, Chem. Commun. 2011, 47, 1976-1978.

[24] L. Huo, L. Ye, Y. Wu, Z. Li, X. Guo, M. Zhang, S. Zhang, J. Hou, Macromolecules 2012, 45, 6923-6929.

[25] H. Wang, F. Liu, L. Bu, J. Gao, C. Wang, W. Wei, T. P. Russell, $A d v$ Mater. 2013, 25, 6519-6525.

[26] S. C. Price, A. C. Stuart, W. You, Macromolecules 2010, 43, 46094612.

[27] W. Guo, S. Wang, K. Sun, M. E. Thompson, S. R. Forrest, $A d v$ Energy Mater. 2011, 1, 184-187.

[28] D. Lee, E. Hubijar, G. J. D. Kalaw, J. P. Ferraris, Chem. Mater. 2012, 24, 2534-2540.

[29] G. G. Malliaras, J. R. Salem, P. J. Brock, C. Scott, Phys. Rev. B 1998 , 58, R13411-R13414.

[30] X. Hu, L. Zuo, W. Fu, T. T. Larsen-Olsen, M. Helgesen, E. Bundgaard, O. Hagemann, M. Shi, F. C. Krebs, H. Chen, J. Mater. Chem 2012, 22, 15710

[31] V. D. Mihailetchi, J. Wildeman, P. W. M. Blom, Phys. Rev. Lett. 2005 , 94, 126602.

[32] J. Liu, H. Choi, J. Y. Kim, C. Bailey, M. Durstock, L. Dai, Adv. Mater. 2012, 24, 538-542.

[33] A. B. Tamayo, X.-D. Dang, B. Walker, J. Seo, T. Kent, T.-Q. Nguyen, Appl. Phys. Lett. 2009, 94, 103301.

[34] J. A. Love, C. M. Proctor, J. Liu, C. J. Takacs, A. Sharenko, T. S. van der Poll, A. J. Heeger, G. C. Bazan, T.-Q. Nguyen, Adv. Funct. Mater. 2013, 23, 5019-5026.

Received: May 2, 2014 Published online: July 13, 2014 